Article

\title{
Surface Ozone Concentration and Its Relationship with UV Radiation, Meteorological Parameters and Radon on the Eastern Coast of the Baltic Sea
}

\author{
Dainius Jasaitis *, Vaida Vasiliauskienè, Renata Chadyšienė and Milda Pečiulienè \\ Department of Physics, Vilnius Gediminas Technical University, Saulètekio Ave. 11, LT-10223 Vilnius, Lithuania, \\ Vaida.Vasiliauskiene@vgtu.lt (V.V.); Renata.Chadysiene@vgtu.lt (R.C.); Milda.Peciuliene@vgtu.lt (M.P.) \\ * Correspondence: Dainius.Jasaitis@vgtu.lt; Tel.: +370-5-274-48-34; Fax: +370-5-270-01-12
}

Academic Editor: Robert W. Talbot

Received: 22 December 2015; Accepted: 29 January 2016; Published: 15 February 2016

\begin{abstract}
Hourly and daily variations of ground-level ozone have been analyzed in relation to meteorological parameters, UVB radiation and radon near the Baltic Sea in Lithuania. An atypical situation with respect to wind domination was observed during the experiment: the wind from the continent was twice as frequent as the wind from the sea. The close correlation between ground-level ozone concentration and UVB radiation intensity was established. The vertical migration directions of ozone and radon were opposite and the negative correlation between these pollutants was observed. The diurnal course of ozone and radon and the influence of meteorological parameters (temperature, relative air humidity, wind speed and direction) on variation of these pollutants have been estimated. It was established that the wind direction domination during the experiment had a significant influence on the variation of ozone and radon concentrations.
\end{abstract}

Keywords: ozone; UV radiation; radon

\section{Introduction}

Recently, the environmental air problems related to the change of ozone volume in the stratosphere and troposphere have become more urgent. Ozone is a toxic air pollutant that is both necessary and harmful to life on earth. The ozone layer in the stratosphere serves as the main barrier protecting us from harmful UV radiation [1,2], therefore the ozone layer decomposition is a global problem that needs to be solved by reducing emissions of the materials destroying the ozone shield (chlorine fluoride hydrocarbons and some other organic halogen formations) into the atmosphere [3].

Ultraviolet radiation is divided into three spectrum ranges according to the length of waves: UVA (315-400 nm), UVB (280-315 nm) and UVC (100-280 nm) [4]. The shorter are the waves, the higher energy they have and the more harmful radiation they possess [5]. The ozone layer absorbs almost all the UVC beams, a major share (95\%) of UVB and only a very small share (5\%) of UVA beams [6]. UVB is the most dangerous radiation that reaches the earth's surface [7]. UV radiation from the sun has both important beneficial and detrimental effects on humans. It damages the main building blocks of human life, i.e., desoxyribonucleic acid (DNA). Surface UV levels are mainly affected by solar zenith angle, clouds, aerosol and surface albedo in addition to ozone [8-10].

The changes of UV radiation intensity resulting from the changes of the stratospheric ozone quantity could alter the concentration of reactive tropospheric gases, including ozone [11,12]. The influence of UV intensity changes could be relevant to the regional scale air quality, since it could alter the short- and long-term concentrations of photo oxidants in the boundary layer. Increased UV radiation intensity enhances photochemical activity in the troposphere [10]. 
There are several sources of ozone in the troposphere: it can be induced by diffusion or intrusive activity from the stratosphere, which results in positive concentration gradient followed by higher ozone concentrations in the free troposphere. Moreover, it can result from discharge in the atmosphere as well as from a product of photochemical reactions in the troposphere [13,14].

Tropospheric ozone is a secondary pollutant formed by solar radiation in a series of photochemical reactions from $\mathrm{NO}_{\mathrm{x}}$ (and volatile organic compounds (VOCs)). The $\mathrm{O}_{3}$ precursor gases $\mathrm{NO}_{\mathrm{x}}, \mathrm{CO}, \mathrm{CH}_{4}$, and VOC are emitted from a wide variety of anthropogenic (e.g., transportation emissions, solvents, and fossil fuels) and natural (e.g., forests, wetlands, soils, and lightning) sources [15,16].

The ground-level ozone concentration is characteristic of strong seasonal, episodic, and diurnal fluctuations [14,17]. The outdoor ozone concentration is not high in Lithuania [18], and the level of $120 \mathrm{\mu g} / \mathrm{m}^{3}$ is only observed less than $10 \%$ of the time.

The results of research in Western Europe showed that the parameters of major importance for the occurrence of photochemical ozone are meteorological parameters $[19,20]$. Thus, researchers state that meteorological conditions have a decisive impact on surface ozone concentrations [21,22].

A close correlation is observed between ozone concentration and radon activity concentration in the atmospheric boundary layer, and the change of the above pollutants in the atmospheric boundary layer is influenced by meteorological parameters; therefore, it is important to evaluate the impact of meteorological parameters on the process of ozone and radon activity concentration in the air of the atmospheric boundary layer.

Chain chemical and photochemical reactions activate the ozone production during daylight hours over the land on a clear day when there is an intense solar radiation $[17,23,24]$, while radon disperses at the same time. The dispersion of radon marks the start of vertical turbulence, which carries radon along with ozone and its precursors to high quotas. Since radon accumulates at night, minimum ozone concentrations are observed: ozone production is not intensive because there is no solar radiation, and ozone is destroyed on the underlying surface by nitrogen oxides and other pollutants in the air $[25,26]$. The nights when radon does not accumulate, but rather remains at low concentrations, are characterized by high levels of ozone, which peak greatly during the first hours after midnight $[27,28]$.

In the daytime, when vertical air mixing is intensive, ozone moves intensively from the higher layers to the ground level of the atmosphere, while radon migrates from the earth to the upper layers of the atmosphere. This determines maximum values of ozone concentration and minimum values of radon volumetric activities during daylight hours. At night, when the inflow of ozone from the higher layers decreases, ozone decay is dominant on the ground level [29].

The radon concentration is dominant on the ground level at night and is caused by decrease of vertical air mixing [30]. However, it is effective only over land, since radon gas emanates from soil where it is formed as a result of ${ }^{226} \mathrm{Ra}$ decaying. Radon emanation and concentration over the water surface is very low. Therefore higher radon concentrations over the sea are observed only in the case of advection from the land. The concentration in soils is typically $10^{5} \mathrm{~Bq} / \mathrm{m}^{3}$ [31], whereas it is only approximately $2 \mathrm{~Bq} / \mathrm{m}^{3}$ in the oceans [32]. Thus, radon emanation is much greater, typically by a factor 100 , over land than over the sea. Vertical mixing of air generally leads to an additional loss of radon at sea level. However, if the upper air comes from over land and the lower air is purely maritime, vertical mixing may cause an increase in radon concentration [33].

The purpose of this experiment was to establish the relationship between surface ozone concentration and UVB radiation intensity, to assess the influence of the meteorological parameters on ozone and radon activity concentrations, and to establish the relationship between these pollutants in the atmosphere on the eastern coast of the Baltic Sea. These combined studies have been carried out in a location with unique landscape (the territory is included on the UNESCO World Heritage List) under atypical meteorological conditions for this region. 


\section{Methods}

The experiment was carried out in Lithuania $\left(55^{\circ} 42^{\prime} \mathrm{N}\right.$ and $\left.21^{\circ} 7^{\prime} \mathrm{E}\right)$ at a site that is $\sim 100 \mathrm{~m}$ from the coast of the Baltic Sea (Figure 1). The site is surrounded by sand dunes seaside, and by pinewood on the continental side. The study location is subject to economic activity restrictrions: the purpose of forests is recreational. The locality is under protection with a view to preserve its authenticity and particularity; however, recently, an increasing flow of people into the are is leading to an increased traffic intensity.

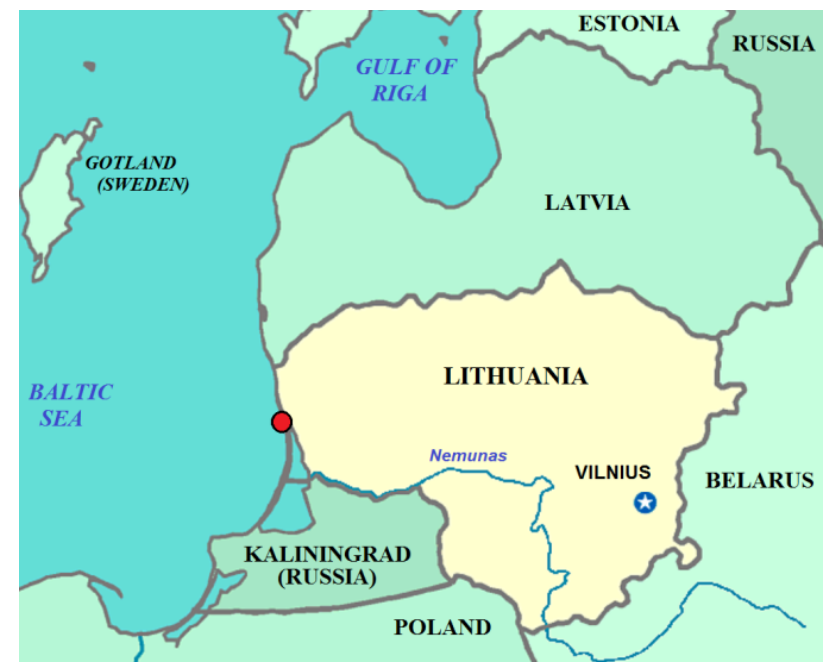

Figure 1. Location of the experiment site.

The measuring equipment included UV radiometer, ozone analyzer, filtration device with a radon radiometer and weather station (Figure 2). All parameters were continuously measured by averaging the five-minute data.

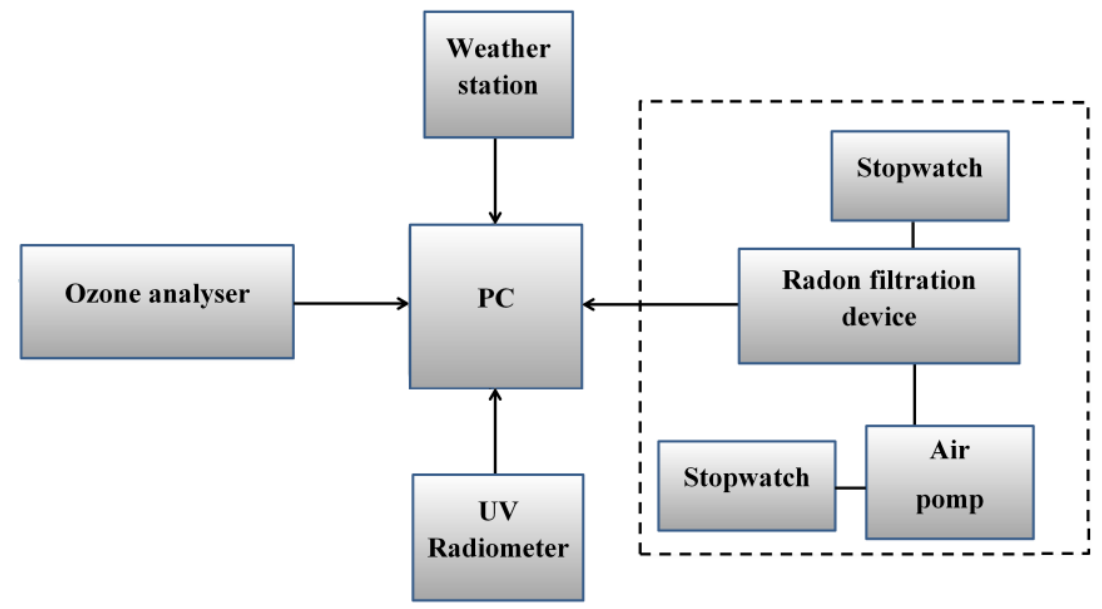

Figure 2. Measurement scheme.

The measurements of UVB radiation intensity were carried out using the radiometer PMA 2200, a sensor that registers UV radiation within the $280-320 \mathrm{~nm}$ spectra. The sensitivity of the sensor was $50 \mathrm{~mW} / \mathrm{cm}^{2}$. The determination error for UVB radiation intensity amounted to $10 \%$.

The ozone concentration was measured with the analyzer ML9811. The operation of this analyzer is based on the principle of ultraviolet absorption. The range of ozone measurements is $0-2000 \mu \mathrm{g} / \mathrm{m}^{3}$, and sensitivity is $2 \mu \mathrm{g} / \mathrm{m}^{3}$. The air was sucked through a Teflon tube at a flow rate of $1.6 \mathrm{~L} / \mathrm{min}$. 
The equipment intended to measure radon and its decay products [34] consists of a filtration device with the radiometer GM-45 and an air volume meter with a pump.

The metal frame of the filtration device has an inlet and outlet: the inlet is used for air suction and a pump is attached to the outlet. The air suction rate is controlled by an air flow meter. The air is sucked through the part of filter band "Fiberglaz", which is between a suction channel and a radiometer. The radiation of the particles settled on the filter is measured with the radiometer GM- 45 .

The radiometer GM-45 is a light and extremely sensitive detector of ionizing radiation. It contains a Geiger-Müller counter that is sensitive to alpha (above $3 \mathrm{MeV}$ ), beta (above $50 \mathrm{keV}$ ), and gamma radiation (above $7 \mathrm{keV}$ ). Use of the RAD (Radiation Acquisition and Display) program (included in this device) enabled data to be stored and transferred into MS Excel where they could be processed. The data were automatically recorded and saved during measurement.

The bias of the method of measurement of radon and its short-lived decay products has been evaluated. It depends on the changes in efficiency of the filter band, the speed of airflow through it, exposition time and the concentration of progeny in the air. It has been found that the bias is not higher than $6 \%$.

The times of air suction and the turn-on time of the filter band are programmed by electronic stopwatches TS-ED1. Having set the hours when the measurements are automatically carried out, the device can operate permanently.

The meteorological parameters were measured by the PC Radio Weather Station. Temperature within the range of $-30{ }^{\circ} \mathrm{C}$ to $+70^{\circ} \mathrm{C}$ was measured with an accuracy of $\pm 1{ }^{\circ} \mathrm{C}$, wind speed in the interval of $0-60 \mathrm{~m} / \mathrm{s}$ was measured with an accuracy of $\pm 0.3 \mathrm{~m} / \mathrm{s}$, wind direction resolution was five degrees, and relative humidity range was from 20 to $100 \%$ with a resolution of $1 \%$. The Radio Weather Station sensors were equipped at a height of $3 \mathrm{~m}$ about $20 \mathrm{~m}$ from the Baltic Sea.

UVB radiation intensity, ozone concentration, activities concentration of radon and all information from the weather station were automatically sent to and recorded on the computer.

\section{Results and Discussion}

Lithuania was influenced by the anticyclone during the first and the last days of the experiment. The sky was mostly cloudless. The temperature varied from 20 to $38^{\circ} \mathrm{C}$, and relative humidity ranged from 25 to $100 \%$. During the experiment, a long period of calm (11\%) was recorded; and a wind speed lower than $1 \mathrm{~m} / \mathrm{s}$ was also identified for $15 \%$ of the observation period. An atypical situation in respect to wind domination during the experiment was recorded: the wind direction is usually from the sea, while wind from the continent is significantly less frequent. However, during the experiment, wind from the continent, i.e., southeastern and eastern ( $39 \%$ and $18 \%$ of the observation period, respectively) were measured, while wind from the Baltic Sea (northwest) blew relatively less frequently ( $30 \%$ of the period).

Ozone concentration, UVB radiation intensity, meteorological parameters and activities concentration of radon were measured at the ground level of the atmosphere in this case.

The average results of UVB radiation intensity and ozone concentration measurements are presented in Figure 3a. The presented results of experimental measurements (taken during the day time) of UVB radiation intensity reveal the same variation of values. Data analysis showed that the $\mathrm{UVB}$ radiation intensity varied from 0.01 to $0.21 \mathrm{~W} / \mathrm{m}^{2}$. The average experimental measurements of UVB radiation intensity show that, at noon, minimum UVB radiation was $0.16 \mathrm{~W} / \mathrm{m}^{2}$, and the maximum determined intensity was $0.21 \mathrm{~W} / \mathrm{m}^{2}$.

UVB radiation has an important role in photochemistry of the troposphere, as it determines the ozone photolysis rate and the resulting formation of $\mathrm{OH}$ radicals [35]. For this reason, changes in UVB radiation may influence ozone concentration. As is known, ozone forms in the binding reaction between atomic oxygen and molecular oxygen, which mostly occurs during electrodischarge (when there is lightning) or in photochemical reaction under the exposure of UV radiation. In large cities where the traffic is intense and air pollution level is high, dangerously high levels of ozone are formed during photochemical reactions. Avino and colleagues [36] investigated this issue for different pollution levels in the atmosphere in detail. 
During the study period, ozone concentration varied from 18 to $119 \mu \mathrm{g} / \mathrm{m}^{3}$. At the same time, a similar ozone level was observed in the surrounding countries, i.e., $4-154 \mu \mathrm{g} / \mathrm{m}^{3}$ (in Latvia), $7-132 \mu \mathrm{g} / \mathrm{m}^{3}$ (in Estonia), 36-118 $\mu \mathrm{g} / \mathrm{m}^{3}$ (in Poland), and 12-167 $\mu \mathrm{g} / \mathrm{m}^{3}$ (in Sweden).

It has been found that the ground-level ozone concentration on the eastern coast of the Baltic Sea may exceed $120 \mu \mathrm{g} / \mathrm{m}^{3}$ under extreme weather conditions, which could have a negative impact on human health.

The air temperature and relative humidity variations in the atmosphere are very closely related. The warm weather was characteristic for the entire experiment period: the temperature varied from 20 to $36^{\circ} \mathrm{C}$ and the relative humidity varied from $32 \%$ to $100 \%$ (Figure $3 b$ ). The highest humidity was observed on the fifth and sixth nights of the experiment, when its value reached approximately $100 \%$. The maximum relative humidity was determined before the sunrise when the lowest air temperature was recorded.

As a result of the analysis of variations in wind direction and speed (Figure 3c), it was established that a breeze was present on the eastern coast of the Baltic Sea during several of the study days. Breezes are not a frequent phenomenon in the region of the Baltic Sea and the processes of air mass transport mostly hide their influence on the level of pollution. During this period, the variations in ozone concentration and radon activity concentration coincided with the daily periodic change of wind direction. During the measurement period, the radon activity concentration varied from 2 to $16 \mathrm{~Bq} / \mathrm{m}^{3}$. The measured average radon activity concentration was $7 \mathrm{~Bq} / \mathrm{m}^{3}$. Ozone concentration was approximately $10-15 \mu \mathrm{g} / \mathrm{m}^{3}$ higher on breezy days than on days when breeze circulation was not observed.

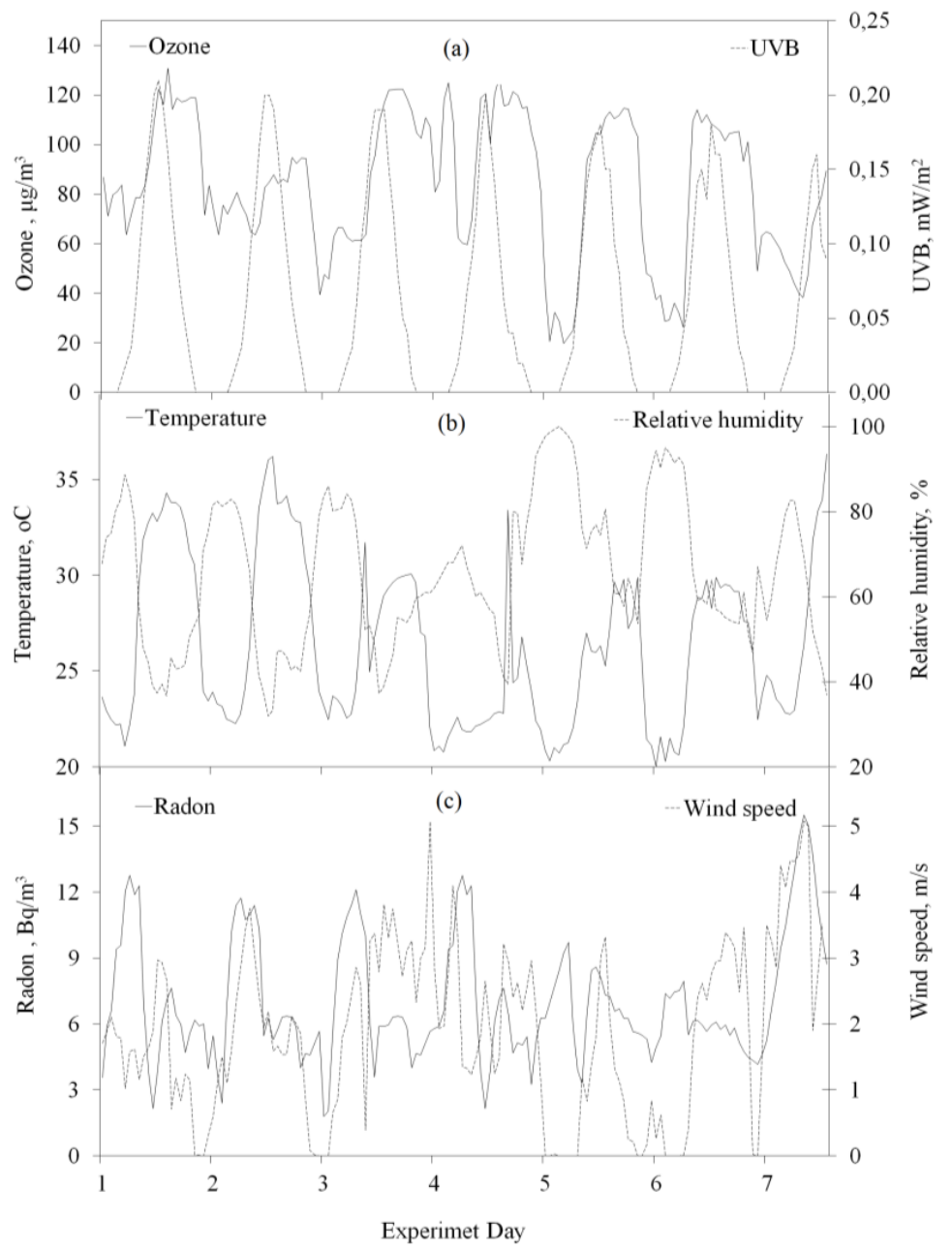

Figure 3. The time course of: (a) UVB radiation intensity and ozone concentration; (b) temperature and relative humidity; and (c) ozone concentration and radon activity concentration. 
Since the experiment site is located in an unpolluted forested area, the photochemical ozone generation can be mostly induced by the natural volatile organic compound emission from vegetation at a certain nitrogen oxide level.

The ground-level ozone concentration versus the daily maximum UVB radiation intensity has been evaluated during research period. Pudasainee and colleagues [37] have found that solar radiation is one of the parameters that have the largest influence on formation of ozone during daylight hours; the correlation coefficient is 0.86 .

The correlation between ozone concentration and UVB radiation intensity was found to be 0.52 . The same range of correlation (0.4-0.6) has been found by Pudasainee and colleagues [37] and An and colleagues [38], while the correlation coefficients for UVB measurements under clear sky conditions and ozone measured by satellite were between 0.85 and 0.95 . The obtained positive correlation coefficient shows the linear relationship between the variables, i.e., with the increase of ultraviolet radiation, the ozone concentration in the ground layer of the atmosphere also increases. The relationship between the hourly ozone concentrations and UV radiations is not very strong, but is significant, i.e., the significance level is $<0.5$.

The values of ground-level ozone concentrations found in the daytime, when UVB radiation intensity is the highest, have been used to establish the relationship between the ground-level ozone concentration and UVB radiation intensity estimation (Figure 4). The results show a significant relationship between these parameters during the entire investigated period.

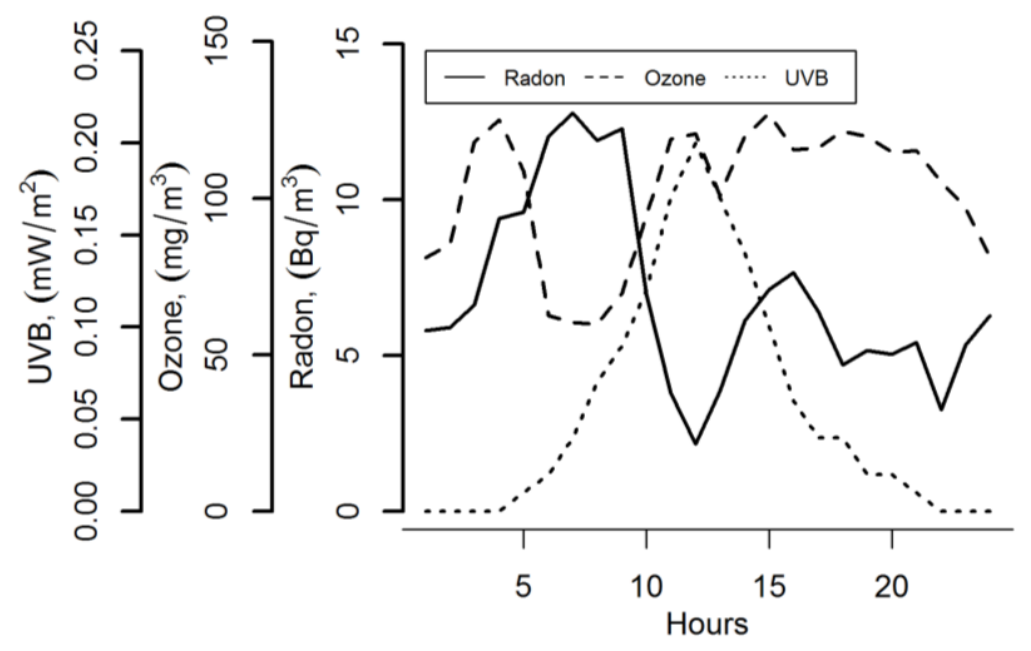

Figure 4. Typical diurnal variation of ozone, UVB and radon.

This indicates that photochemical ozone production is strongly related to the variation of the UVB radiation intensity.

The results of measured ozone concentration showed significant diurnal variations (Figure 4). The maximum average ozone concentration was found in the afternoon, while the minimum value was observed at night and early in the morning. Changes in the ground-level ozone concentration are determined by vertical air mixing, photochemical ozone production or its decay. The intensity of photochemical ozone production or vertical air mixing is the highest during the daytime, when the high environmental temperature and low relative air humidity are recorded, while, at night, these processes are less intensive. Moreover, ozone concentration decreases at night, also as a result of reactions with nitrogen oxides. Nitrogen oxides form during the combustion process, and their main source is transportation. By taking into consideration the fact that the traffic flows in the study area are increasing, it is conceivable that the levels of nitrogen oxides, which influence ozone formation, are also increasing. However, the economic activity is not carried out in the study area; therefore, there are 
no thermal power plants or factories, which are also sources of nitrogen oxides emissions. Therefore, the level of nitrogen oxides in the study area is significantly lower than that in urbanized areas.

The radon concentration (Figure 4) undergoes a typical diurnal variation over the land in the case of anticyclone with a maximum value during the night and a minimum value in the afternoon, which may be explained by the formation of thermal inversions during the night. Air radioactivity starts to increase from approximately 10:00-11:00 P.M. The maximum value is reached from 5:00-6:00 A.M., just before the sunrise. Meanwhile, the minimum values are observed at about noon. This might be explained by the fact that activity concentration of radon is influenced by the intensity of air turbulence. During the day, the earth's surface is warmed by the sun and positive temperature gradient occurs above the surface of the earth. In the evening, when the sun's warming is not effective, the positive temperature gradient is constantly moving towards the negative one. The slow variation in temperature is characteristic for the night period. The temperature gradient significantly decreases and is time-variable close to the surface of earth, i.e., 0.1-0.2 $\mathrm{m}$ above the ground. At this time, increase in activity concentration of radon continues and reaches the maximum value. After sunrise, air temperature is constantly increasing, and the temperature gradients decrease in all layers. Temperature inversion is typical for this period.

The detailed study of the diurnal variations of ozone and $\mathrm{NO}_{x}$ as well as their variation depending on the different seasons and the influence of radon on their dynamics was carried out by Avino and colleagues [39]. They also found the diurnal variation of radon and ozone concentration analogous to our study results.

Desideri and colleagues [27] and Di Carlo and colleagues [40] measured radon activity concentration and ozone concentration simultaneously. It was found that under fine weather conditions, the correlation coefficient of these values often exceeds 0.8 , and that this is related to the fact that the directions of vertical flows of radon and ozone in the ground-level of the atmosphere are opposite.

When the weather is calm and fine, conditions favorable to the accumulation of pollutants at the ground level of the atmosphere occur and in such cases their concentrations may significantly increase. Such conditions can occur when the weather is determined by anticyclone (an area of high atmospheric pressure): the weather is calm, windless and rainless. Such weather dominated during the period of our experiment. The cyclone approached the territory of Lithuania on two days of the experiment (Days 5 and 6 in Figure 3). During the rainy period, the activity concentration of radon decreased. The radon decay products usually bind to the aerosol particles, which are always in the air, and the fall washes them out from the air. It has been observed that ozone concentration decreased during the rainy period; however, the analysis data has shown that the influence of relative humidity on ozone concentration is less significant than that on concentration of radon. The negative correlation between ozone concentration and relative air humidity has been observed. Baciu and Zoran and colleagues [41,42] have found that outdoor radon activity depends on the physiognomy of atmospheric circulation and on rain. It has been found that after rain or snow, radon activity in the atmosphere decreases.

The analysis on interrelations among ozone concentration, radon activity concentration and wind speed has been carried out. The research revealed that the stronger the wind is, the higher the ozone concentration recorded. This might be associated with the fact that both the stronger wind and the higher ozone concentration are recorded during the daytime. The search for the relationship between ozone concentration and wind speed showed that maximum ozone concentration was observed when the wind speed did not exceed $3 \mathrm{~m} / \mathrm{s}$. The lowest ozone concentration $\left(\sim 36 \mu \mathrm{g} / \mathrm{m}^{3}\right)$ was recorded when there was no wind at all. It should be noted that relative air humidity was approximately $100 \%$ at that time.

Radon activity concentration decreased with increase of wind speed: radon gas is better dispersed in the atmosphere. However, it has been established that, in this case, activity concentration of radon is more influenced by wind direction (low-speed winds dominated during the experiment). Desideri and colleagues [27] and Smetanova and colleagues [33] presented results obtained by performing measurements above the sea. It was found that measurement activities depend on the pressure and direction of the wind with respect to land. Continuous measurements were carried out 
inside and outside of buildings [43]. It was found that the clear maximum of radon concentrations is observed at low air turbulence outdoors, which, in turn, has an influence on the formation of the maximum radon activity concentrations indoors.

The influence of wind direction on variation in ozone concentration and activity concentration of radon has been estimated (Figure 5).

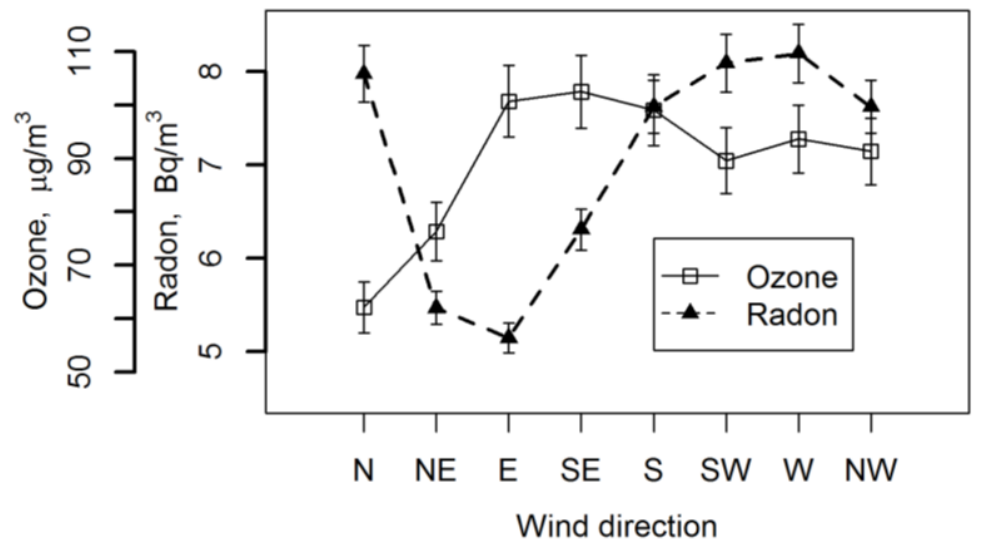

Figure 5. Relationship between wind direction and average concentrations of ozone and radon activity.

The maximum value of radon activity concentration was observed when the wind blew from the continent, and the minimum value was observed when the wind blew from the sea. This shows soil being the largest source of radon, as is the case in Lithuania and other countries. Therefore, when wind blows from the sea, radon gas diffuses in the atmosphere.

Low ozone decay to the surface of water was the reason for higher ozone concentration in the case of the wind blowing from the sea in comparison with the ozone concentration in the case of the wind blowing from the continent. Dry deposition rate for ozone to the surface of water is $0.53-1.1 \mathrm{~mm} / \mathrm{s}$, while it is $7 \mathrm{~mm} / \mathrm{s}$ to a field and it may even exceed $21 \mathrm{~mm} / \mathrm{s}$ to a forest.

In addition to other processes in the atmosphere (increased turbulence, photochemistry (increased UVB radiation intensity), etc.), which increase ozone concentration during daylight hours, wind also contributes to such increase. Due to the specific circulation, the ozone-rich air from the higher layers is brought to the measurement place and since it moves above the water, ozone decay is decreased.

The well-known chemical inertness of these gases and the known half-life of radon (3.82 days) make radon a useful sample in examination of air mass changes. For example, it is often used for approving global atmospheric transfer models [44].

Zoran and colleagues [45] have assessed the air quality and its relationship with radon. Daily mean concentrations of particle matter, ozone, nitrogen dioxide, sulfur dioxide and global air quality indices have been analyzed in relation with the ground-level radon concentrations. Such new information is relevant to atmospheric sciences with a view to prove suitability of radon as a tracer for atmospheric dynamics analysis as well as to epidemiological and radiological protection studies.

In Avino and colleagues' paper [46], the influence of the meteorological conditions on the pollution levels and trends in the megacity Rome were shown. The importance of the natural beta radiation was revealed and the formation of smog photochemical pollution was described by the authors.

Avino and colleagues [36] found that radon and its short-lived decay products could be considered a valuable indicator showing the degree of mixing in the low atmospheric layer.

Data from the eastern coast of the Baltic Sea in Lithuania are quite scarce. We think that it must be the object of future studies. 


\section{Conclusions}

- The data analysis of the combined studies of surface ozone concentration, UV radiation, meteorological parameters and radon carried out at the Eastern Coast of the Baltic Sea under an atypical meteorological situation in this area shows clearly expressed diurnal courses of these parameters and the significant relationships among them.

- The statistically significant correlation between the UVB radiation intensity and ground-level ozone concentration has been determined, and the obtained correlation coefficient between these values was 0.52 . Photochemical ozone production is strongly related to the change of the UVB radiation intensity within the exclusive territory of the Baltic Sea coast.

- Meteorological parameters such as relative humidity, wind speed and wind direction have various effects on ozone concentration at the ground level of the atmosphere. Data analysis has shown that surface ozone concentrations increase with the increase of temperature; however, it is not significantly related to relative air humidity. It was observed that ozone concentration decreased during the rainy period. However, the wind direction had the largest influence on the variation of ozone concentrations during the study period.

- Interdependence between ozone concentration and radon activity variations has been observed. The clear inverse diurnal course of these pollutants has been determined. The especially clearly expressed relationship between these pollutants has been observed under the conditions of anticyclone. Radon activity concentration is inversely correlated with the level of vertical mixing in the atmospheric surface layer, which is one of the most important factors of ozone variability.

- A higher ozone concentration in the atmospheric boundary layer was found when the wind blew from the Baltic Sea towards the continent due to low rate of ozone decay to the water surface. Higher radon activity concentrations were found when the wind blew from the continent. The simultaneous measurements of the ground-level ozone concentration and radon activity concentration gave the possibility of identifying the presence of a breeze phenomenon on the eastern coast of the Baltic Sea under extreme weather conditions in summer.

Acknowledgments: The research presented in this paper is supported by Faculty of Fundamental Sciences of Vilnius Gediminas Technical University.

Author Contributions: The study has been completed with the cooperation of all authors.

Conflicts of Interest: The authors declare no conflict of interest.

\section{References}

1. Previdi, M.; Polvani, L.M. Climate system response to stratospheric ozone depletion and recovery. Q. J. R. Meteorol. Soc. 2014, 140, 2401-2419. [CrossRef]

2. Revell, L.E.; Tummon, F.; Stenke, A.; Sukhodoloy, T.; Coulon, A.; Rozanov, E.; Garny, H.; Grewe, V.; Peter, T. Drivers of the tropospheric ozone budget throughout the 21st century under the medium-high climate scenario RCP 6.0. Atmos. Chem. Phys. 2015, 15, 5887-5902. [CrossRef]

3. Zhang, H.; Wu, S.; Huang, I.; Wang, I. Effects of stratospheric ozone recovery on photochemistry and ozone air quality in the troposphere. Atmos. Chem. Phys. 2014, 14, 4079-4086. [CrossRef]

4. Aggarwal, A.; Kumari, R.; Mehla, N.; Deepali; Singh, R.P.; Bhatnagar, S.; Sharma, K.; Sharma, K.; Vashishtha, A.; Rathi, B. Depletion of the ozone layer and its consequences: A review. Am. J. Plant. Sci. 2013, 4, 1990-1997. [CrossRef]

5. Yagura, T.; Makita, K.; Yamamoto, H.; Menck, C.F.; Schuch, A.P. Biological sensors for solar ultraviolet radiation. Sensors 2011, 11, 4277-4294. [CrossRef] [PubMed]

6. Tian, J.Y.; Yu, J. Changes in ultrastructure and responses of antioxidant systems of algae (Dunaliella salina) during acclimation to enhanced ultraviolet-B radiation. J. Photochem. Photobiol. B Biol. 2009, 97, 152-160. [CrossRef] [PubMed] 
7. Zerefos, C.S.; Tourpali, K.; Eleftheratos, K.; Kazadzis, S.; Meleti, C.; Feister, U.; Koskela, T.; Heikkilä, A. Evidence of a possible turning point in solar UV-B over Canada, Europe and Japan. Atmos. Chem. Phys. 2012, 12, 2469-2477. [CrossRef]

8. Vaida, V.; Feierabend, K.J.; Rontu, N.; Takahashi, K. Sunlight-initiated photochemistry: Excited vibrational states of atmospheric chromophores. Int. J. Photoenergy 2008, 138091, 1-13. [CrossRef]

9. Bordi, I.; Berrilli, F.; Pietropaolo, E. Long-term response of stratospheric ozone and temperature to solar variability. Ann. Geophys. 2015, 33, 267-277. [CrossRef]

10. Feister, U.; Cabrol, N.; Häder, D.-P. UV irradiance enhancements by scattering of solar radiation from clouds. Atmosphere 2015, 5, 1211-1228. [CrossRef]

11. Doherty, R.M.; Wild, O.; Shindell, D.T.; Zeng, G.; MacKenzie, I.A.; Collins, W.J.; Fiore, A.M.; Stevenson, D.S.; Dentener, F.J.; Schultz, M.G.; et al. Impacts of climate change on surface ozone and intercontinental ozone pollution: A multi-model study. J. Geophys. Res. Atmos. 2013, 118, 3744-3763. [CrossRef]

12. Anet, J.G.; Rozanov, E.V.; Muthers, S.; Peter, T.; Brönnimann, S.; Arfeuille, F.; Beer, J.; Shapiro, A.I.; Raible, C.C.; Steinhilber, F. Impact of a potential 21st century "grand solar minimum" on surface temperatures and stratospheric ozone. Geophys. Res. Lett. 2013, 40, 4420-4425. [CrossRef]

13. Wargan, K.; Pawson, S.; Stajne, I.; Thouret, V. Spatial structure of assimilated ozone in the upper troposphere and lower stratosphere. J. Geophys. Res. 2010, 115, D24316. [CrossRef]

14. Monks, P.S.; Archibald, A.T.; Colette, A.; Cooper, O.; Coyle, M.; Derwent, R.; Fowler, D.; Granier, C.; Law, K.S.; Stevenson, D.S.; et al. Tropospheric ozone and its precursors from the urban to the global scale from air quality to short-lived climate forcer. Atmos. Chem. Phys. 2015, 15, 8889-8973. [CrossRef]

15. Lang, C.; Waugh, D.W.; Olsen, M.A.; Douglass, A.R.; Liang, Q.; Nielsen, J.E.; Oman, L.D.; Pawson, S.; Stolarski, R.S. The impact of greenhouse gases on past changes in tropospheric ozone. J. Geophys. Res. Atmos. 2012, 117, D23304. [CrossRef]

16. Young, E.; Paton-Wash, C. Emission ratios of the tropospheric ozone precursors nitrogen dioxide and formaldehyde from Australia's black Saturday fires. Atmosphere 2011, 2, 617-632. [CrossRef]

17. Khoder, M.I. Diurnal, seasonal and weekdays-weekends variations of ground level ozone concentrations in an urban area in greater Cairo. Environ. Monit. Assess. 2009, 149, 349-362. [CrossRef] [PubMed]

18. Girgždienè, R.; Byčenkienè, S.; Girgždys, A. Variations and trends of AOT40 and ozone in the rural areas of Lithuania. Environ. Monit. Assess. 2007, 127, 327-335. [CrossRef] [PubMed]

19. Andersson, C.; Engardt, M. European ozone in a future climate: Importance of changes in dry deposition and isoprene emissions. J. Geophys. Res. Atmos. 2010, 115, D02303. [CrossRef]

20. Katragkou, E.; Zanis, P.; Tsikerdekis, A.; Kapsomenakis, J.; Melas, D.; Eskes, H.; Flemming, J.; Huijnen, V.; Inness, A.; Schultz, M.G.; et al. Evaluation of near-surface ozone over Europe from the MACC reanalysis. Geosci. Model. Dev. 2015, 8, 2299-2314. [CrossRef]

21. Toh, Y.Y.; Fook, L.S.; von Glasow, R. The influence of meteorological factors and biomass burning on surface ozone concentrations at Tanah Rata, Malaysia. Atmos. Environ. 2013, 70, 435-446. [CrossRef]

22. Civerolo, K.; Hogrefe, C.; Lynn, B.; Rosenthal, J.; Ku, J.Y.; Solecki, W.; Cox, J.; Small, C.; Rosenzweig, C.; Goldberg, R.; et al. Estimating the effects of increased urbanization on surface meteorology and ozone concentrations in the New York City metropolitan region. Atmos. Environ. 2007, 41, 1803-1818. [CrossRef]

23. Panday, A.; Prinn, R.G. Diurnal cycle of air pollution in the Kathmandu Valley, Nepal: Observations. J. Geophys. Res. 2009, 114, D09305. [CrossRef]

24. Putero, D.; Cristofanelli, P.; Marinoni, A.; Adhikary, B.; Duchi, R.; Shrestha, S.D.; Verza, G.P.; Landi, T.C.; Calzolari, F.; Busetto, M.; et al. Seasonal variation of ozone and black carbon observed at Paknajol, an urban site in the Kathmandu Valley, Nepal. Atmos. Chem. Phys. Discuss. 2015, 15, 22527-22566. [CrossRef]

25. Tong, N.Y.O.; Leung, D.Y.C.; Liu, C.-H. A review on ozone evolution and its relationship with boundary layer characteristics in urban environments. Water Air Soil Pollut. 2011, 214, 13-36. [CrossRef]

26. Banerjee, A.; Archibald, A.T.; Maycock, A.C.; Telford, P.; Abraham, N.L.; Yang, X.; Braesicke, P.; Pyle, J.A. Lightning NOx, a key chemistry-climate interaction: Impacts of future climate change and consequences for tropospheric oxidizing capacity. Atmos. Chem. Phys. 2014, 14, 9871-9881. [CrossRef]

27. Desideri, D.; Roselli, C.; Meli, M.A.; Feduzi, L. Comparison between the diurnal trends of ozone and radon gas concentrations measured at ground in the semi-rural site of Central Italy. J. Radioanal. Nucl. Chem. 2007, 273, 345-351. [CrossRef] 
28. Kalbarczyk, R.; Kalbarczyk, E. Assessment of the value of tropospheric ozone concentration depending on meteorological conditions as exemplified by the Widuchowa station (north-West Poland). Ekol. Bratisl. 2010, 29, 398-411. [CrossRef]

29. Kulkarni, P.S.; Bortoli, D.; Silva, A. Nocturnal surface ozone enhancement and trend over urban and suburban sites in Portugal. Atmos. Environ. 2013, 71, 251-259. [CrossRef]

30. Postawczyńska, A.; Kozak, K.; Pawlak, W.; Mazur, J. Seasonal and diurnal variation of outdoor radon $\left({ }^{222} \mathrm{Rn}\right)$ concentrations in urban and rural area with reference to meteorological conditions. Nukleonika 2010, 55, 543-547.

31. Ghita, A.; Vasilescu, A. Radon assessment with solid-state nuclear track detectors in Bucgarest and its surrounding region. Rom. Rep. Phys. 2011, 63, 940-947.

32. Burnett, B.; Nelson, T.; Corbett, R.; Robinson, L.; Weaver, J.; McKisson, J.E.; Lane-Smith, D. Improvements the measurement of Rn-222 in natural waters. In Proceedings of the 44th Annual Conference on Bioassay, Analytical, and Environmental Radiochemistry, Albuquerque, NM, USA, 7-11 November 1998.

33. Smetanova, I.; Holy, K.; Muellerova, M.; Polaskova, A. The effect of meteorological parameters on radon concentration in borehole air and water. J. Radioanal. Nucl. Chem. 2009, 283, 101-109. [CrossRef]

34. Jasaitis, D.; Girgždys, A. Hourly measurement method for radon progeny volumetric activity in air. J. Environ. Eng. Landsc. 2007, 15, 158-165.

35. Diffey, B.L. Solar ultraviolet radiation effects on biologicalm systems. Phys. Med. Biol. 1991, 36, $299-328$. [CrossRef] [PubMed]

36. Avino, P.; Manigrasso, M. Ozone formation with combustion processes in highly populated urban areas. AIMS Environ. Sci. 2015, 2, 764-781. [CrossRef]

37. Pudasainee, D.; Balkrishna, S.; Shrestha, M.L.; Kaga, A.; Kondo, A.; Inoue, Y. Ground level ozone concentrations and its association with $\mathrm{NO}_{x}$ and meteorological parameters in Kathmandu valley, Nepal. Atmos. Environ. 2006, 40, 8081-8087. [CrossRef]

38. An, J.L.; Wang, Y.S.; Li, X.; Sun, Y.; Shen, S.H. Relationship between surface UV radiation and air pollution in Beijing. Environ. Sci. 2008, 29, 1054-1058.

39. Avino, P.; Manigrasso, M. Ten-year measurements of gaseous pollutants in urban air by an open-path analyzer. Atmos. Environ. 2008, 42, 4138-4148. [CrossRef]

40. Di Carlo, P.; Pitari, G.; Mancini, E.; Gentile, S.; Pichelli, E.; Visconti, G. Evolution of surface ozone in central Italy based on observations and statistical model. J. Geophys. Res. 2007, 112, D10316. [CrossRef]

41. Baciu, A.C. Radon and thoron progeny concentr ation variability in relation to meteorological conditions at Bucharest (Romania). J. Environ. Radioact. 2005, 83, 171-189. [CrossRef] [PubMed]

42. Zoran, M.; Dida, M.R.; Savastru, R.; Savastru, D.; Dida, A.; Ionescu, O. Ground level ozone $\left(\mathrm{O}_{3}\right)$ associated with radon $\left({ }^{222} \mathrm{Rn}\right)$ and particulate matter $(\mathrm{PM})$ concentrations and adverse health effects. J. Radional. Nucl. Chem. 2014, 300, 729-746. [CrossRef]

43. Porstendorfer, J.; Butterweck, G.; Reineking, A. Daily variation of indoor radon concentration indoors and outdoors and the influence of meteorological parameters. Health Phys. 1994, 67, 283-287. [CrossRef] [PubMed]

44. Dörr, H.; Kromer, B.; Levin, I.; Munnich, K.O.; Volpp, H.J. $\mathrm{CO}_{2}$ and radon-222 as tracers for atmospheric transport. J. Geophys. Res. 1993, 88, 1309-1313. [CrossRef]

45. Zoran, M.; Savastru, D.; Dida, A. Assessing urban air quality and its relation with radon $\left({ }^{222} \mathrm{Rn}\right)$. J. Radional. Nucl. Chem. 2016, 1-14. [CrossRef]

46. Avino, P.; Manigrasso, M.; Cuomo, F. Natural radioactivity as an easy and quick parameter for describing the dynamic of the Planetary Boundary Layer. RSC Adv. 2015, 5, 57538-57549. [CrossRef]

(C) 2016 by the authors; licensee MDPI, Basel, Switzerland. This article is an open access article distributed under the terms and conditions of the Creative Commons by Attribution (CC-BY) license (http://creativecommons.org/licenses/by/4.0/). 